\title{
Teaching Methodology and Performance of Private and Government School Teachers: A Comparative Analysis
}

\author{
Malik Tayyab Ali* \\ Department of Commerce and Finance, Superior University, Lahore, Pakistan \\ Irsa Azam \\ Department of Management Sciences, University of Gujrat, Punjab, Pakistan \\ Kashif Ali \\ Department of Commerce and Finance, Superior University, Lahore, Pakistan
}

\begin{abstract}
The research is financed by Asian Development Bank. No. 2006-A171(Sponsoring information)
\end{abstract}
\section{Abstract}

The study tries to seek the teaching methodology between private and government schools by using mediating variable that put influence directly on overall performance of both the sectors. In this study, primary data are used through questionnaires. The study indicates the difference of quality of education in private and government schools in Pakistan's education system. Findings of the study show that private schools show better performance as compare to government schools. The study suggests government schools to improve the quality of education.

Keywords: Private and Government School, Teaching Methodology, Teaching Quality, Teaching Responsibilities, Teacher Efficacy.

DOI: $10.7176 / \mathrm{JEP} / 11-16-02$

Publication date:June 30th 2020

\section{Introduction}

For any nation educations is considered a very vital elements of monetary and community evolution and human composition. Frequently, efficacy education research claimed that the significance in class what is held on in perspective of intellectual and non-intellectual conclusion. Through education, adeptness and work rate of any individual are raised for tenable economic development (Nasir and Iqbal, 2009). To implement the free education developing countries present a short budget according to their resources to their civilians. On education, only $2 \%$ of its GNP is allocated in Pakistan (Pakistan Government, 2009). For economic development, Illiteracy is considered the central obstruction. Almost $90 \%$ students in primary level and $70 \%$ of secondary students are registered in public sector over the developing countries. Especially in developing countries, the public sector cannot maintain the quality of education due to quickly expanding population-containing Pakistan with 2.7\% growth rate of population (Pakistan Government, 2010-2011).

In Pakistan, the education system is an in-heritage of British law in Sub-Continent. Primary and secondary level of education is well correlated with public and private sector. At the time of independency are categorized the educational organization into two classifications (Burki, 1986). First is that Provincial government handle the public school and colleges, second is that Private school play a vital act to providing the Education through school at this time. (Shami and Hussain) claimed that in Punjab 48,541, Sindh 12,574, NWFP 11,276, Baluchistan 1750, ICT 750, FATA 640, and FANA 2861 and in AJK 2711 private organizations of education are exist and total private institute is 81,103 .

\subsection{Public School Performance VS Private School Performance}

Mostly studies have been conducted to comparative analysis between Government and Private schools and their effectiveness. Comparative analysis between American student's performance in Math subject shows the results that private school conduct extra performed than public school (Lubiensk et al. 2006, Peterson and Llaudet 2006). As per to National Assessment of Educational Progress (NAEP) that is delegate at the national dimensions for evaluation American's student's information in all area including Science subjects reported that Private institute performed superior rather than Public school (U.S. Department of Education 2012). However, Watkins (2006), claimed that NAEP data on the base of appearance public and private sector is not suitable to judge the performance.

In All Education Conference 1947 built three fundamental endorsements, first is Islamic Education should be compulsory, second is Elementary Education must should be free and compulsory, and last is that to focus on Technical Education. In school to improve the student's Academic favorable outcomes, Principal and teachers play a important role according to the country Culture, Ideological, Civil and Religious standards but unluckily in Pakistan these standards are not valuable. 


\subsection{Research Objectives}

In this study is objectives are

1. To identify the quality of Education in Private and Government school

2. To compare the overall performance between Private and Government school

\subsection{Research Question}

Basic questions in this study are "Comparative analysis of Teaching Methodology between private and government school teacher on student's performance at Primary level: A case study of District Narowal Tehsil Shakargarh-Pakistan."

\section{Literature Review}

Previous study reported that response to heterogeneity in Qualifications, Gender, Age Factor and school of staff self-esteem graduated system majority alike but morale of Government school is lower as compare to Private school (Mustaqeem, 2008). Another research study claimed that face annoyed as compared to Private school teachers the mostly Government school teachers act well, avoid disagreeing and accuse to others (Shaheen, 2008). Liaqat (2009) investigated that in Private school the quality of educations is much better than Government school while Private school teachers before teaching prepared the lesson and then came into the classroom as compared to Government school teachers.

Another study shows that Private head teacher focused on co-curricular activities in the institute while Government school head teacher performed well related to administrative planning for the year (Fairda and Madeeha, 2000). Jimenz and Tan (1985) investigated that in Private school regardless of the Evolutions, Educational institute did not deliver the measurement of Pakistan state. This study shows expulsion of Ladies in rural site mostly disturbed in Private school and tuition and other fees so enough. Author examined that Private school provide facilities for rich people i.e. an enlistment of 2.1 Million children.

Alderman et al (2001) claimed that performance inputs in Private school better than Government school. Key points in this study are that survey is based on household-level. Another researcher reported that to enhance the teaching quality performance judgments are used that measure the level of knowledge, methodology, classroom atmosphere, and teacher inspiration and students' manners. Study reported that the performance appraisal in private school is good as compared to Government school, also results in Government school are not good and there is need to improve the Government sector (Khan et al., 2014).

Almani et al (2012) studied that the parents, students, teachers, and officers' behavior for to evaluate the basic standards of educations in Private school of Sindh and to measure the performance of parents, students, teachers, and officers against the higher position in private organizations. Data taken from four vital elements of Private school in which 360 students. 220 teachers, 220 parents, 80 civil servants, 90 school and question were adopted on the basis of four different point of view in which one is quality and quantity of Private school teachers, role of students and support by parents and standards of textbook. Findings in this study is that Private school teacher focus to provide the good educations, implement the rules and regulations, do hard work with honestly, try to support to each other and avoid misunderstanding and splendid future plan.

One more studied conducted in Indonesia to analyze the influence between Private and Government school in communicable the labor market profits as to examine the efficacy by ruling the individual traits and school selection process. Findings in this study reported that benefits of Private school do much better perform as compare to Government school (Bedi et al, 2000). In developing country even in developed nations the Private schools are not out performed. According to survey in Logos State, Nigeria and identify that $75 \%$ children were enlisted in Private school. While in private school, the activities of teaching are higher than Government school (Tooley et al., 2005). Coulson (2009) reported to her study that generally achievements of Private school for supplies of educations in mostly cases are outperformed in world.

Similarly, in Kenya the study was conducted in Africa Private education, where in 2004-2007 ratio of primary school increase $4.6 \%$ to $11.5 \%$. After announcement the unfunded Primary Education Policy (FPE) by Kenya Government in 2003, Study found that proportions of Teacher-Pupils increased in Government school, Parents respond to shift their child in Private school (Nishimura \& Yamano, 2013). Selvam (2014) discussed in their study that in all education method to learn successfully a class teacher to hold the students engaged. Teachers are always try use latest education technique to understand the concept clear, well-defined of students because students can bring successful conclusion at the end of class that is helpful to improve their teaching skills for a teacher.

\subsection{Conceptual Framework}

The Figure 1 shows the conceptual framework of the study. 


\section{Research Methodology}

3.1 Data and Types

For this study, primary data are used based on questionnaire that is filled from teachers, senior teachers and head-teachers of the school. For this study, there are two groups exist; one is Private school and second is Government school. Findings are introduced through SPSS Software.

\subsection{Population and Sample}

Total 40 schools are used for the study in which 20 were private sector and other 20 are taken Government sector in rural areas of District Narowal Tehsil Shakargarh. Sample was taken from every school in both sector and information collected from teachers who teach their students in these education institutions.

\subsection{Measurement of Variable}

In this study to analyze the performance of private school and performance of government school were taken as a dependent variable, teacher method taken as an independent variable and teaching quality, teacher responsibilities, teachers efficacy are used as mediating variables. Table 1 elaborated the selected proxies of variables.

\section{Empirical Findings}

\subsection{Demographic Profile Respondent's}

Total 40 questions were distributed in Private and Government school to teachers, senior teachers and headteachers. Respondents of demographic profile is elaborated in table 2 that consist information on all components on the basis of Gender, Age, Qualification, Job Experience, Staff Designation and Monthly Income.

Table 2 indicates that out of 39 respondents, $19(50 \%)$ are Male and $19(50 \%)$ are Females; two respondents not take information about their gender. Age respondents is 37 in which Under 25 is 16 (43\%), 25-35 are 12 $(33 \%), 35-45$ are $5(14 \%), 45-55$ are $2(5 \%)$ and Above 55 are $2(5 \%)$; three are missing that not to response about age factor that show mostly response in this study are under 16 and three not take inform about your age. Of the respondents 34, intermediate are $6(18 \%)$, Bachelor Degree holder are $12(35 \%)$ and Master or above Degree holder are 16 (47\%); that show in this study Master or Above level educators exist. Out of 36 in which $26(72 \%)$ have job experience in $1-5$ year, 6-10 year are $8(22 \%)$ and Above 10 years are $2(6 \%) ; 72 \%$ are those who have 1-5 year experienced and 4 are given response about your job experience. Of the 39 respondents, teachers are $26(67 \%)$, senior teacher are $11(28 \%)$ and head teachers are $2(5 \%)$; that shows mostly staff designation reported as young teacher $67 \%$ out of $100 \%$. Out of 32 monthly incomes respondent, below 15000 rupees are $7(22 \%)$, within range $15000-25000$ rupees are $8(25 \%)$, within the range of 25000-35000 rupees are $14(44 \%)$ and above 35000 rupees are $3(9 \%)$. In this study, 8 respondents are not give responses.

\subsection{Descriptive Statistics of Survey Items}

In this study question are contained 28 items that vary from to each other's. The range of Mean score in different items from 2.53 to 4.49 and the range score of standards deviations were exist between 0.816 to 1.386 (see table $3)$ that is described in details.

\subsection{Cronbach's Alpha Analysis}

Cronbach's coefficient alpha analysis is used for to measure the reliability of the given data that data are reliable or not reliable. Table 4 represents the estimated values of Cronbach's coefficient alpha. Teaching method (alpha $=0.950)$, Teaching quality (alpha $=0.853$ ), Teachers responsibilities (alpha=0.938), Teacher efficacy (alpha $=0.700)$, performance in private school (alpha $=0.831$ ), performance in Government school (alpha $=0.789$ ). In shortly, higher the value of Cronbach's alpha shows higher the reliability measurement of the construct. In sample represent Cronbach's alpha value varies from (0.700 to 0.950). Table 4 represents the value of Cronbach's alpha in details. Hinton et al (2014) explained about Cronbach's alpha value for measure the reliability in SPSS that if value of Cronbach's alpha exists between ( 0.5 and below) shows low reliability, value is stand between the range of $(0.50-0.70)$ say moderate reliability, Cronbach's alpha value within $(0.70-0.90)$ shows high reliability and if values are stand between (above 0.90) then say that excellent reliability between them.

\subsection{Factor Analysis}

Factor analysis technique is used to reduce the data items for check the validity of the data. In order to approve the construct validity (Convergent and discriminant validity); by using Principle Components Analysis (PCA) method with Varimax Rotation Approach, the factor analysis was conducted. In Varimax rotation method, Kaiser-Meyer Olkin (KMO) measure that data are adequacy for apply in Factor Analysis. Sampling adequacy demonstration the stability of relation among variables although sphericity test are used to measure the 
correlation of components.

\subsection{KMO measure of Sampling Adequacy Test and Bartlett's Test of Sphericity}

Kaiser-Meyer Olkin used to measure the sampling adequacy that shows the validity of teaching methodology factor analysis. KMO value varies between (0-1). 0 value of KMO indicates bigger dispersal in design of correlations and 1 value of KMO signify the design of correlation are approximately condensed. Generally, Rule of Thumb shows that KMO values 0.5 are poor, 0.6 are generally acceptable and KMO value 1 indicates better and desirable (Hinton et al., 2014).

Table 5 reported the value of KMO of every construct well according to above recommendation. $(\mathrm{KMO}=0.910)$ for Teaching method, $(\mathrm{KMO}=0.733)$ for Teaching Quality, $(\mathrm{KMO}=0.886)$ for Teacher Responsibilities, $(\mathrm{KMO}=0.628)$ for Teacher Efficacy, $(\mathrm{KMO}=0.821)$ for Performance in Private School and $(\mathrm{KMO}=0.701)$ for performance in Government School. All KMO value within range according to (Hinton et al, 2014). Bartlett's test of sphericity analysis used to measure the significances of relationship between the numbers of items. Normally, p-value less than 0.05 confirmed the significant of relationship between variables. In this study, Table 5 indicates the value of $\mathrm{P}$ of Bartlett's test that shows all respondent are less than 0.001 , which give proof against Null hypothesis of no correlations. That is valuable for run the Factor Analysis.

\subsection{Eigenvalues}

Eigen values measure for further analysis. Hinton et al (2014) reported that Eigen values always equal or greater than 1. Table 6 indicates all components eigenvalues and indicates the all percentage of explained variance for construct. TM (existing of seven items explained variance $77.477 \%$ ), TQ (existing of three items explained variance $77.663 \%$ ). TR (containing of five items explained variance $82.041 \%$ ), TE (consist of three items explained variance $62.773 \%$ ), PPS (including of five items explained variance $60.066 \%$ ) and PGS (containing of five items explained variance 54.459\%). In Table 6 in all construct the value of are greater than 1.

\subsection{Factor Loadings and Correlation Analysis}

In factor loading two value are existed in which one is Loading which have minimum value should be greater than 0.4 and second is Cross Loading that should not to be above 0.40 (Straub et al, 2012). For all items (i.e. Teaching Method, Teaching Quality, Teaching Responsibilities, Teacher Efficacy, Performance in Private School and Performance in Government School) are shows in the range of Loaded Factor from 0.821 to 0.904, 0.776 to $0.788,0.813$ to $0.918,0.483$ to $0.757,0.601$ to 0.787 and 0.4 to 0.816 respectively.

Before to run the regression model for analysis, firstly to measure the Pearson Correlation Analysis between the variables. Table 8 indicates the correlation value among the variables.

\subsection{Regression Analysis}

Regression Analysis run to measure the impact of Teaching Methodology (independent variable) on mediating variables (i.e. Teaching Quality, Teaching Responsibilities and Teacher Efficacy) and to see the effect of Mediating variables on Dependent variables (Performance of Private School and Performance of Government School). Figure 2 shows a significant relationship between the variables.

\section{Conclusion}

Education considered are a vital element in the world level that provides the social economic progress in a country. Quality of education system is meager due to valuable reasoning that Pakistan Government gives priority on quantity education nor quality of the education and try to introduce free education. As known without teaching methodology, teaching quality, teaching responsibilities and teacher efficacy cannot improve the quality of educations in the country. Source of person preferred to Private school instead of Government school, so Government should to focus on quality of education not quantity of education. Present study in this paper indicates the result that Performance in Private school is much satisfied as compared the Performance in Government School. For this study sample are taken in 20 private school and 20 in Government school which are based on questionnaire. A case of District Narowal Tehsil Shakargarh.

\section{References}

Alderman, H., Orazem, P. F., \& Paterno, E. M. (2001). School quality, school cost, and the public/private school choices of low-income households in Pakistan. Journal of Human resources, 304-326.

Almani Abdul Sattar, S. B. (2012). "Evaluative Study of Private Schools Pakistan: A Survey of Sindh. Indus Journal of Management \& Social Sciences, 6(2), $91-98$.

Bedi, A. S., \& Garg, A. (2000). The effectiveness of private versus public schools: The case of Indonesia. Journal of Development Economics, 61(2), 463-494

Burki. (1986). Pakistan: A Nation in the Making. Westview Press. 
Coulson, A. J. (2009). Comparing Public, Private, And Market Schools The International Evidence. Journal Of School Choice, 3(1), 31-54.

Farida, B., \& Madiha, K. (2000). A Comparative Study of Administrators' Role in Public and Private Secondary Schools. Un published Master thesis, Institute of Education and Research, University of Punjab, Lahore.

Hinton, P. R., McMurray, I., \& Brownlow, C. (2014). SPSS explained. Routledge.

Jimenez, E., \& Tan, J. P. (1985). Educational development in Pakistan: The role of user charges and private education. The World Bank.

Khan, H. M. A., Chandio, J. H., \& Farooqi, M. T. K. (2014). Comparison of performance appraisal system in public and private schools. Pakistan Journal of Commerce and Social Sciences (PJCSS), 8(1), 278-288.

Liaqat. (2009). Comparison of Quality of teaching between Government. and Private schools. Unpublished Thesis of Master in Education. Division of Education, University of Education, Lahore.

Lubienski, C., \& Lubienski, S. (2006). Charter, private, public schools and academic achievement: New evidence from NAEP mathematics data

Mustaqeem, S. (2008). A comparative study of Staff Morale of Public and Private school in Lahore. Unpublished Thesis of Master in Education. Division of Education, University of Education, Lahore.

Nasir, Z. M., \& Iqbal, N. (2009). Employers size wage differential: does investment in human capital matter?. The Pakistan Development Review, 509-521.

Nishimura, M., \& Yamano, T. (2013). Emerging private education in Africa: Determinants of school choice in rural Kenya. World Development, 43, 266-275.

Peterson, P. E., \& Llaudet, E. (2006). On the public-private school achievement debate.

Ringle, C. M., Sarstedt, M., \& Straub, D. W. (2012). Editor's Comments: A Critical Look at the Use of PLSSEM in" MIS Quarterly". MIS quarterly, iii-xiv.

Selvam, D. (2014). Digital Teaching and Learning.

Shaheen, R. (2008). A Comparative Study of Aggressive Behavior of Public and Private School Teachers in Lahore. Unpublished Thesis of Master in Education. Division of Education, University of Education, Lahore.

Tooley, J., Dixon, P., \& Olaniyan, O. (2005). Private and public schooling in low-income areas of Lagos State, Nigeria: A census and comparative survey. International Journal of Educational Research, 43(3), 125-146.

Watkins, S. (2006). Are Public or Private Schools Doing Better? How the NCES Study Is Being Misinterpreted. Backgrounder No. 1968. Heritage Foundation.

\section{Appendix}

Table 1: Variables Description

\begin{tabular}{cc}
\hline Proxy Variables & Details of Proxy Variable \\
\hline PPS & Performance in Private School \\
PGS & Performance in Government school \\
TM & Teaching Methodology \\
TQ & Teaching Quality \\
TR & Teacher Responsibilities \\
TE & Teacher Efficacy \\
\hline
\end{tabular}


Table 2: Demographic Profile Respondent's

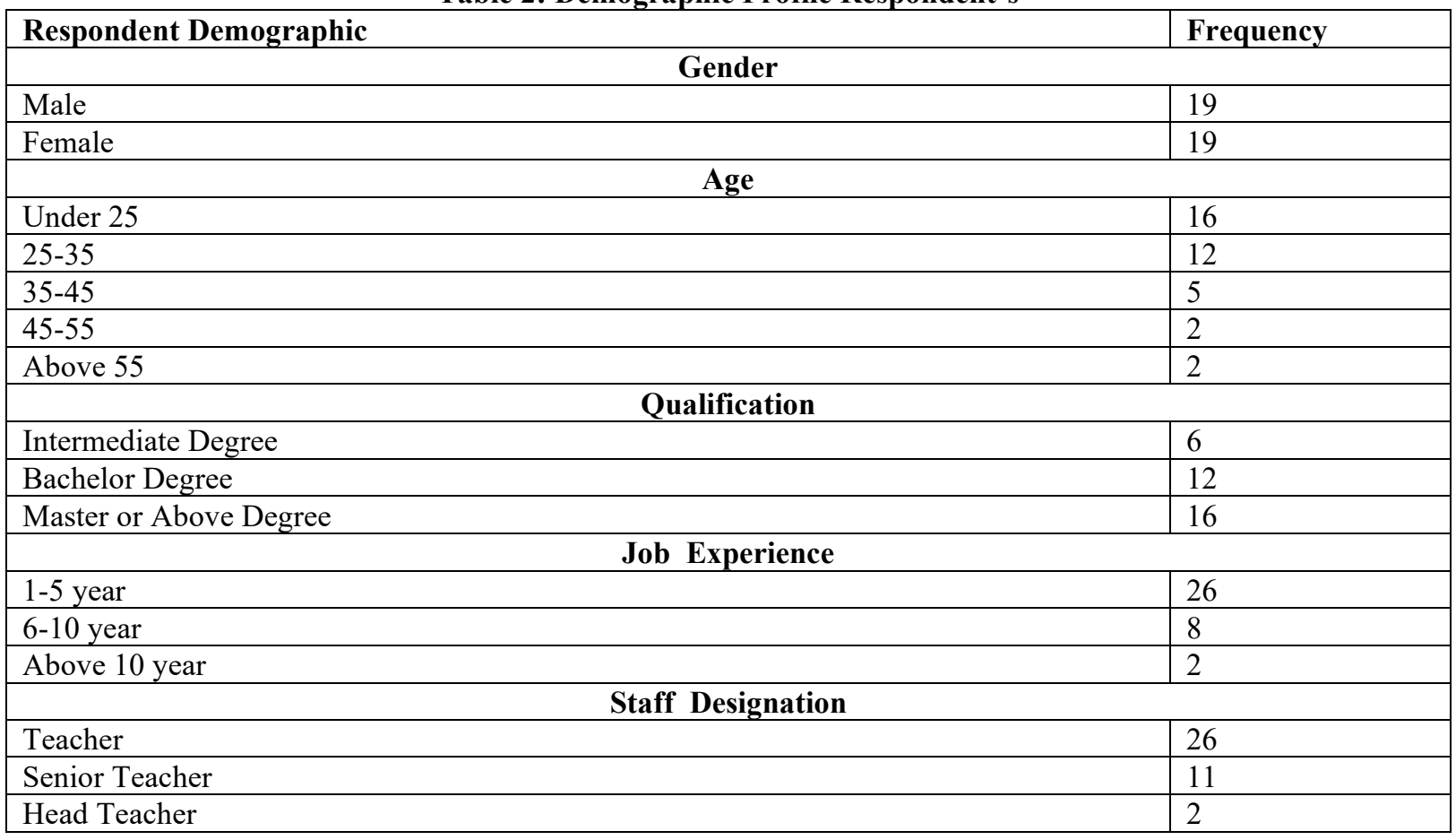

Table 3: Descriptive Statistics

\begin{tabular}{|c|c|c|c|c|c|}
\hline Descriptive Statistics & $\mathbf{N}$ & Min. & Max. & Mean & S.D. \\
\hline Expectation to end all work & 37 & 1 & 5 & 3.32 & 1.132 \\
\hline Punish student for not getting work & 40 & 1 & 5 & 3.55 & 1.061 \\
\hline Teacher help you to learn a lesson & 40 & 1 & 5 & 3.48 & 1.062 \\
\hline Teacher help during working together & 38 & 1 & 5 & 3.68 & 1.165 \\
\hline To ask the class what they think about work & 40 & 1 & 5 & 3.40 & 0.982 \\
\hline Teacher would be enthusiastic in lessons & 40 & 2 & 5 & 3.40 & 0.955 \\
\hline Teacher would explain things clearly & 40 & 1 & 5 & 3.38 & 0.868 \\
\hline Teaching profession is good & 40 & 2 & 5 & 3.45 & 0.904 \\
\hline Teachers are interest in students & 40 & 1 & 5 & 3.53 & 1.062 \\
\hline Teacher praise efforts & 40 & 1 & 5 & 3.43 & 0.984 \\
\hline To feel a waste of time to attempt to do best as a teacher & 40 & 1 & 5 & 3.18 & 1.259 \\
\hline Making a difference in lives between students & 39 & 1 & 5 & 3.31 & 1.436 \\
\hline I am not want to teach them & 39 & 2 & 5 & 4.49 & 0.854 \\
\hline Feel responsibilities for students to teach not for other students in school & 40 & 1 & 5 & 3.05 & 1.197 \\
\hline Teachers expected to maintain discipline entire school not in class & 40 & 1 & 4 & 2.98 & 1.097 \\
\hline I enjoy the present teaching job & 40 & 1 & 5 & 2.90 & 0.928 \\
\hline To make a difference in children's lives & 40 & 1 & 5 & 2.83 & 0.903 \\
\hline I would choose teaching again & 39 & 1 & 4 & 2.69 & 1.080 \\
\hline Help all students to achieving high standards & 38 & 2 & 5 & 3.89 & 0.953 \\
\hline Understand different students in a class for learning & 40 & 1 & 5 & 2.53 & 0.987 \\
\hline $\begin{array}{l}\text { Develop a curriculum that builds on students experience, interest and } \\
\text { abilities }\end{array}$ & 40 & 1 & 5 & 2.53 & 0.816 \\
\hline Use instructional strategies for promote active students learning & 40 & 1 & 4 & 2.53 & 0.905 \\
\hline i don't feel sense of belongingness to this institution & 40 & 1 & 5 & 3.53 & 1.176 \\
\hline Help all students to achieving standards & 40 & 2 & 5 & 4.08 & 0.971 \\
\hline Understand different students in a class for learning & 39 & 1 & 5 & 3.97 & 1.386 \\
\hline $\begin{array}{l}\text { Develop a curriculum that builds on students experience, interest and } \\
\text { abilities }\end{array}$ & 39 & 1 & 5 & 3.90 & 1.353 \\
\hline Use instructional strategies for promote active students learning & 40 & 1 & 5 & 3.40 & 1.336 \\
\hline i don't feel sense of belongingness to this institution & 39 & 1 & 5 & 3.23 & 1.202 \\
\hline Valid N (listwise) & 28 & & & & \\
\hline
\end{tabular}


Table 4: Cronbach's alpha analysis for Reliability

\section{Constructs}

\begin{tabular}{l|l} 
& Number of Items
\end{tabular}

Teaching Method

Teaching Quality

Teacher Responsibilities

Teacher Efficacy

Private School Performance

Government School Performance

\begin{tabular}{|c|c|}
\hline Number of Items & Cronbach's Alpha \\
\hline 7 & 0.95 \\
\hline 3 & 0.853 \\
\hline 5 & 0.938 \\
\hline 3 & 0.7 \\
\hline 5 & 0.831 \\
\hline 5 & 0.789 \\
\hline
\end{tabular}

Table 5: KMO and Bartlett's Test

\begin{tabular}{|l|c|r|r|r|}
\hline \multicolumn{1}{|c|}{ Constructs } & No. of Items & \multicolumn{1}{c|}{ KMO } & \multicolumn{1}{c|}{ BTScs } & \multicolumn{1}{c|}{ BTSs } \\
\hline Teaching Method & 7 & 0.910 & 216.673 & .000 \\
\hline Teaching Quality & 3 & 0.733 & 50.064 & .000 \\
\hline Teacher Responsibilities & 5 & 0.886 & 166.692 & .000 \\
\hline Teacher Efficacy & 3 & 0.628 & 22.049 & .000 \\
\hline Performance in Private School & 5 & 0.821 & 65.442 & .000 \\
\hline Performance in Government school & 5 & 0.701 & 55.316 & .000 \\
\hline P & 5 & & \\
\hline
\end{tabular}

Note: a: KMO Measurement of sample adequacy, b: Bartlett's Test of Sphericity Chi-Square, c: Bartlett's Test of Sphericity sig.

Table 6: Eigenvalues and Total Explained Variance

\begin{tabular}{|l|c|c|c|c|}
\hline Construct & Components & Total & $\begin{array}{c}\text { \%o of explained } \\
\text { variance }\end{array}$ & $\begin{array}{c}\text { Cumulative \% of } \\
\text { explained variance }\end{array}$ \\
\hline Teaching Method & 7 & 5.423 & 77.477 & 77.477 \\
\hline Teaching Quality & 3 & 2.33 & 77.663 & 77.663 \\
\hline Teaching Responsibilities & 5 & 4.102 & 82.041 & 82.041 \\
\hline Teacher Efficacy & 3 & 1.883 & 62.773 & 62.773 \\
\hline Performance in Private School & 5 & 3.003 & 60.066 & 60.066 \\
\hline Performance in Government School & 5 & 2.723 & 54.459 & 54.459 \\
\hline
\end{tabular}

Table 7: Components Matrix

\begin{tabular}{|l|c|}
\hline Items & Component \\
\hline Teaching Method & TM \\
\hline Expectation to end all work & 0.821 \\
\hline Punish student for not getting work & 0.883 \\
\hline Teacher help you to learn a lesson & 0.833 \\
\hline Teacher help during working together & 0.904 \\
\hline To ask the class what they think about work & 0.876 \\
\hline Teacher would be enthusiastic in lessons & 0.821 \\
\hline Teacher would explain things clearly & 0.881 \\
\hline Teaching Quality & TQ \\
\hline Teaching profession is good & 0.781 \\
\hline Teachers are interest in students & 0.776 \\
\hline Teacher praise efforts & 0.788 \\
\hline Items & Component \\
\hline Teaching Responsibilities & TR \\
\hline To feel a waste of time to attempt to do best as a teacher & 0.813 \\
\hline Making a difference in lives between students & 0.918 \\
\hline I am not want to teach them & 0.891 \\
\hline Feel responsibilities for students to teach not for other students in school & 0.901 \\
\hline Teachers expected to maintain discipline entire school not in class & 0.915 \\
\hline Teaching Efficacy & TE \\
\hline I enjoy the present teaching job & 0.656 \\
\hline To make a difference in children's lives & 0.483 \\
\hline I would choose teaching again & 0.757 \\
\hline
\end{tabular}




\begin{tabular}{|l|c|}
\hline Items & Component \\
\hline Performance In Private School & PPS \\
\hline Help all students to achieving high standards & 0.761 \\
\hline Understand different students in a class for learning & 0.793 \\
\hline Develop a curriculum that builds on students experience, interest and abilities & 0.601 \\
\hline Use instructional strategies for promote active students learning & 0.766 \\
\hline i don't feel sense of belongingness to this institution & 0.787 \\
\hline Performance In Government School & PGS \\
\hline Help all students to achieving high standards & 0.393 \\
\hline Understand different students in a class for learning & 0.746 \\
\hline Develop a curriculum that builds on students experience, interest and abilities & 0.816 \\
\hline Use instructional strategies for promote active students learning & 0.600 \\
\hline I don't feel sense of belongingness to this institution & 0.782 \\
\hline
\end{tabular}

Table 8: Pearson's Bivariate Correlation Analysis

\begin{tabular}{|l|c|c|c|c|c|c|}
\hline Variables & TM & TQ & TR & TE & PPS & PGS \\
\hline Teaching Methodology & 1 & $.833^{* *}$ & $.954^{* *}$ & $.876^{* *}$ & $.902^{* *}$ & $.808^{* *}$ \\
\hline Teaching Quality & & 1 & $.821^{* *}$ & $.744^{* *}$ & $.830^{* *}$ & $.631^{* *}$ \\
\hline Teaching Responsibilities & & & 1 & $.848^{* *}$ & $.911^{* *}$ & $.817^{* *}$ \\
\hline Teacher Efficacy & & & & 1 & $.822^{* *}$ & $.656^{* *}$ \\
\hline Performance in Private School & & & & & 1 & $.757^{* *}$ \\
\hline
\end{tabular}

\section{$\underline{\text { Figures }}$}

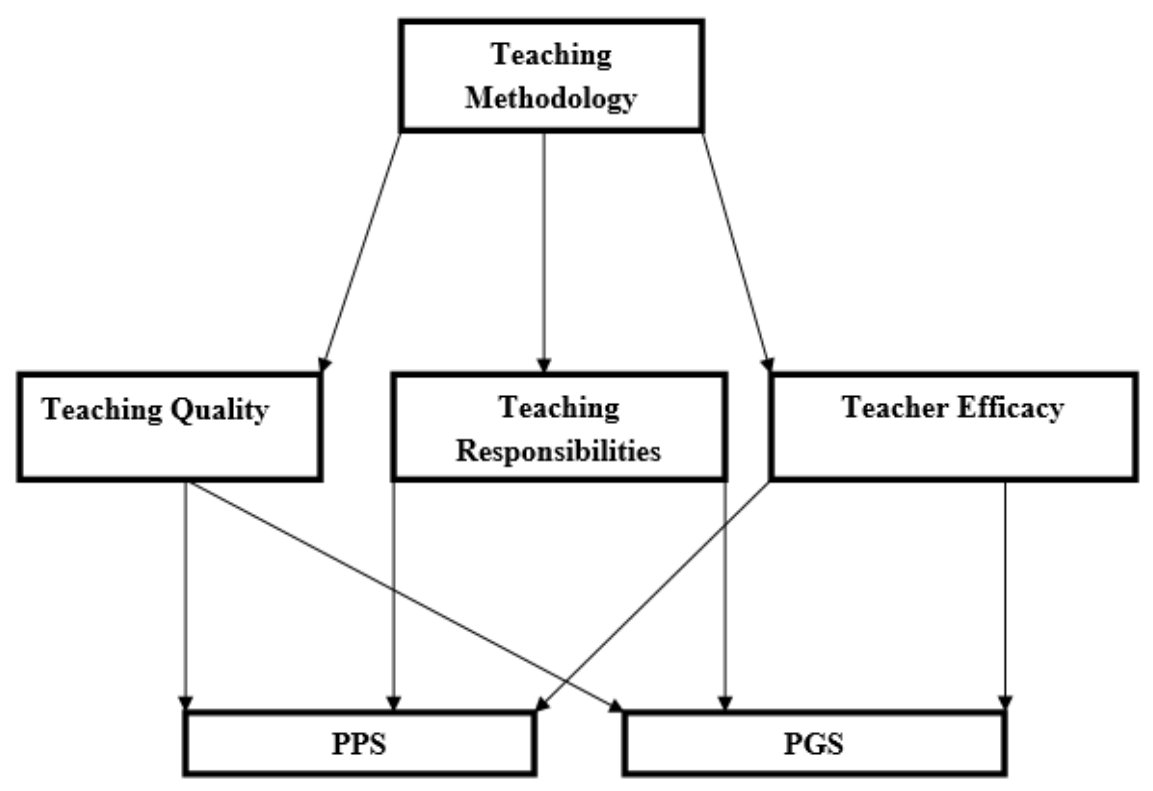

Figure 1: Conceptual Framework 


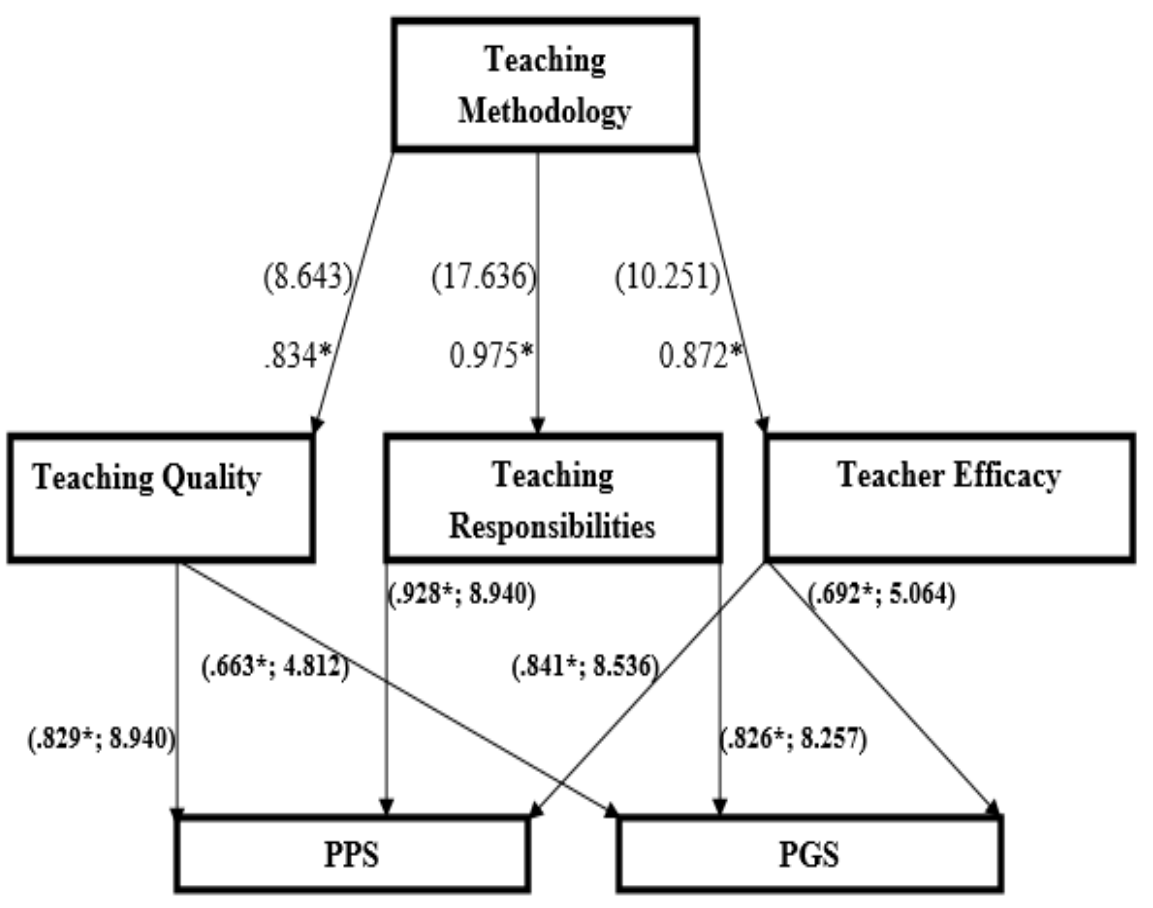

Figure 2: Structural Relations Among Variables 